\title{
Slot-machine approach to science in Australia's upbeat budget
}

\section{Sydney}

Australia's treasurer has pulled an almost unbelievable rabbit out of the hat - a balanced budget - although he has had to sell $\mathrm{A} \$ 1,000$ million in assets, such as a large slice of the prime real estate beneath the Australian embassy in Tokyo, to do it. The financial sector loved it, the stock market rose, interest rates fell, and the Australian dollar strengthened. For science, the news is not so good. The treatment it received prompted the Minister of Science and Small Business, $\mathrm{Mr}$ Barry Jones, to criticize his own government for the low priority it gave science and for approaching research funding with a "slot-machine mentality".

"After 15 years, there is no longer a Department of Science", according to Jones, who feels that science has fallen off Australia's political agenda completely. The Department of Science, which he headed until the election last July, has been relegated to the status of a junior ministry within the Department of Industry, Trade and Commerce (DITAC), with some responsibilities being moved to other departments.

Jones holds scientists largely responsible for this situation, often criticizing them for their failure to take their cause to the public. "Unfortunately, science is both politically invisible and tongue-tied", he says. He attacks the attitude of government bureaucrats in financial and coordinating departments, saying that they are hostile towards research without the immediate prospect of economic return. He says "The very concept of 'curiosity-led' research drives many into a frenzy: it is seen as little more than a hobby, like stamp-collecting or knitting, at public expense."

Hardest hit is Australia's large research agency, the Commonwealth Scientific and Industrial Research Organization (CSIRO), one body that has stayed with Jones with his move to DITAC. CSIRO's allocation has been cut from $\mathrm{A} \$ 364$ million last year to $\mathrm{A} \$ 354$ million this year, a cut of about 10 per cent, allowing for inflation. CSIRO is expected to make up the shortfall through sales of assets and by attracting more money from industry.

One innovation to emerge from the budget is the creation of the Australian Research Council (ARC), with a budget allocation of A $\$ 67$ million. The Australian Science and Technology Council (ASTEC) recommended the formation of ARC to coordinate diverse science-funding schemes. ASTEC suggested that $\mathrm{A} \$ 66$ million be provided in 1987-88 to start ARC, but also said that the money should not be taken from universities' general funds, as the level of funding is already perilously low, and that ARC should be part of the Department of Science.

The A\$67 million that the ARC has received is a sham because the government has included in it the Commonwealth postgraduate awards scheme, whose sizeable budget was not included in ASTEC's calculations, as well as taking A $\$ 5$ million from the general allocation to universities. The inclusion of the ARC in the newly created portfolio of Education, Employment and Training worries many academics because, although paying lipservice to the importance of fundamental research, the man responsible for it, exminister for Resources and Energy $\mathrm{Mr}$ John Dawkins, like senator John Button, the man in charge of DITAC, does not share Jones's passion for science. Dawkins's actual commitment to pure research will become clear when its representation on the council, whose member-

\section{Prize season begins with awards for many}

This year's winners of the Albert Lasker awards are three molecular geneticists and a psychiatrist, while a physical anthropologist and a psychologist are among the three Balzan prize winners.

The Lasker medical research prize is for work on the genetic control of antibody diversity. It is shared by Leroy Hood of the California Institute of Technology, Philip Leder of Harvard Medical School and Susumu Tonegawa of the Massachusetts Institute of Technology. Tonegawa, a graduate of Kyoto University, carried out much of the relevant research while at the Basel Institute of Immunology, and many of Leder's contributions derive from his time at the National Institutes of Health in Bethesda.

Morgens Schou, research director of the psychopharmacology research unit of the Aarhus University Institute of Psychiatry at Risskov, Denmark, receives the Lasker clinical research prize for pioneering the use of lithium to treat manic-depressive illness.

Although the Lasker prizes are widely

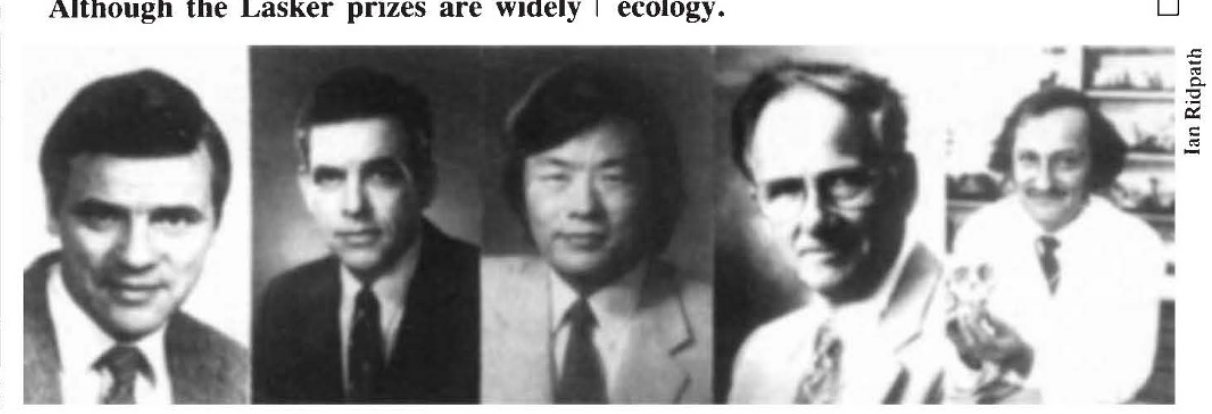

Lasker winners (left to right) Hood, Leder, Tonegawa and Schou. Right, Balzan winner Tobias with Taung skull.

ship will be announced soon, is known.

The bright spot in this year's budget is in Button's territory, the funding of research in industry, where money for the grants for industrial development (GIRD) scheme has been increased from $\mathrm{A} \$ 10.8$ million to A $\$ 25.6$ million in 1987-88. GIRD is for research in small, innovative, 'start-up' companies with a turnover too small to take advantage of the 150 per cent research and development tax concession.

The Department of Education, Employment and Training has been given a mandate to create 5,800 places in universities and colleges of advanced education for young school-leavers, though it is not clear where the money to do so will come from. They have, however, been given an extra A\$31 million to create 13,000 short-term traineeships aimed at young, unemployed people.

The overall position is summed up by the Australian Academy of Science, who found that although total Commonwealth Government outlays had increased by 4.3 per cent, all outlays in the budget classified as scientific research have increased by just 0.8 per cent. Charles Morgan respected and frequently a good predictor of Nobel prizes, they are cash-poor; Leder, Hood and Tonegawa share $\$ 15,000$. By contrast, the Balzan prize winners each receive 250,000 Swiss francs, about $\$ 165,000$. This year's winners of the prizes, which go to the arts as well as to the sciences, include Philip Tobias of the University of Witwatersrand Medical School, for his studies of hominid fossils and evolution, and Jerome Bruner, of the New School of Social Research in New York for his contributions in the field of human psychology.

Meanwhile, brothers Eugene P. Odum, of the University of Georgia, and Howard T. Odum, of the Univeristy of Florida, pick up $\$ 250,000$ at the award ceremony this week for the 1987 Crafoord prize. Awarded by the Royal Swedish Academy of Sciences within areas of science not covered by the Nobel prizes, this year it was the turn of biosciences. The Odums receive their award in Stockholm for their pioneering contributions to ecosystem ecology. 